\title{
An experimental orthopedic treatment of the rat mandible using a functional appliance alters the fibre and myosin types in masticatory muscles
}

\author{
Claudine OUDET, A. PETROVIC, Pascale GARCIA \\ INSERM, U 213, Faculté de Médecine \\ 4, rue Kirschleger, 67085 Strasbourg Cedex, France.
}

\begin{abstract}
Summary. Masticatory muscles mediate the action of functional orthopedic appliances on mandible growth. When young rats were treated for four weeks with a postural hyperpropulsor of the mandible, an applicance designed to increase condylar cartilage growth rate, the proportion of fast non-fatigable fibres in the lateral pterygoid muscle increased significantly. Concomitantly, the amount of slow-myosin light chains increased in fibre extracts. This slow myosin originated from IIA fibres. By functional orthopedic treatment, the lateral pterygoid muscle was enriched in less fatigable fibres; the changes observed in the lateral pterygoid muscle were close to changes observed in other muscles after training.
\end{abstract}

\section{Introduction.}

In dentofacial orthopedics, specific cases of mandibular retrognathia require treatment with a « functional type " appliance (Petrovic, Lavergne and Stutzmann, 1986). These appliances are removable; children wear them part-time daily. In specific cases of malocclusion resulting from mandibular growth insufficiency, the wearing of "activators" or "propulsors » is indicated. Such appliances are designed to increase the growth rate of condylar cartilage and consequently to lengthen the mandible (Charlier, Petrovic and Herrmann-Stutzmann, 1969). The effectiveness of the treatment depends on numerous regulating factors having the form of a servosystem (Petrovic, 1975, 1984). Among these factors, the muscles of mastication and mandibular protrusion play an important part (Petrovic, Stutzmann and Oudet, 1975 ; Oudet and Petrovic, 1981).

An experiment in growing rats was designed in order to detect therapeutically-induced variations in the length of the individual sarcomeres and variations in the proportion of fibre and myosin types.

\section{Material and methods.}

Twenty 50-day old male Sprague-Dawley rats were used. Half of the rats wore a « postural hyperpropulsor » of the mandible $8 \mathrm{~h}$ daily. The appliance was an inclined plane fitted on the upper incisors that forced the rats to push the mandible in a more forward position each time the mouth tended to close. The other half of the animals served as controls. The experiment lasted 4 weeks. 
Length of sarcomeres in lateral pterygoid muscle during the treatment with the mandibular postural hyperpropulsor. - The heads of non-treated 7-week old rats were fixed in a buffered glutaraldehyde solution. During fixation, several sagittal deviations ( $0 \mathrm{~mm}$, i.e. controls, $1 \mathrm{~mm}, 1.5 \mathrm{~mm}$ and $2 \mathrm{~mm}$ ) were imposed on the occlusal adjustment of the mandible to the maxilla. The lateral pterygoid muscle was dissected with its attachments. This muscle has no tendon; the individual fibres running from the pterygoid process of the sphenoid to the mandibular condyle were separated by teasing. Sarcomeres were counted on an average of six portions from ten fibres. The length of an individual sarcomere was calculated by the length of the fibre portion divided by the number of sarcomeres.

Lateral pterygoid muscles from rats treated for 4 weeks with a postural hyperpropulsor of the mandible producing a $1-\mathrm{mm}$ forward sagittal deviation, were fixed in their occusal position at killing. Sarcomere length was measured as mentioned above.

ATPase activity. - The ATPase activity of lateral pterygoid muscle fibres was evidenced on frozen sections. The assay was carried out according to the method of Brooke and Kaiser (1970). After 15-min preincubation in acid solution ( $\mathrm{pH} 4.4$ or $\mathrm{pH} 4.5$ ), the sections were incubated for $30 \mathrm{~min}$ in a $2.7 \mathrm{M}$ ATP solution at $\mathrm{pH}$ 9.4. The sections were impregnated with a cobalt solution. With an ammonium chloride solution, cobalt ions were precipitated as cobalt sulfide. Object slides were prepared for observation under a microscope.

PAGE of myosin light chains. - Frozen sections of the inferior head of the lateral pterygoid muscle were made. Muscle proteins were extracted from the sections according to the method of Mabuchi et al. (1981). An SDS-polyacrylamide gel electrophoresis after Laemmli (1970) was run. $15 \%$ polyacrylamide gels were $0.7 \mathrm{~mm}$ thick ; they were stained with R-250 Coomassie blue and destained with $7 \%$ acetic acid. Finally, the gels were silver-stained according to Ansorge (1983).

\section{Results.}

Variations of sarcomere length in lateral pterygoid muscle related to sagittal deviations of occlusal adjustment.

In controls, the length of an individual sarcomere was $2.5 \mu \mathrm{m}$ (fig. 1). The length of the sarcomere did not depend on rat age : $2.47 \mu \mathrm{m}, 2.46 \mu \mathrm{m}$ and $2.45 \mu \mathrm{m}$ (SE : 0.02) were observed respectively in 20,48 and 78 -day old rats. These values are in agreement with an estimation reported by Rayne and Crawford (1972). When the mandible was fixed in various forward positions causing a sagittal deviation of $1 \mathrm{~mm}, 1.5 \mathrm{~mm}$ and $2 \mathrm{~mm}$, sarcomere length was $2.05,1.85$ and $1.65 \mu \mathrm{m}$, respectively (fig. 1 ).

When the postural hyperpropulsor of the mandible was fitted every day for $8 \mathrm{~h}$ over 4 weeks, muscle growth increased less. Indeed, on an average, 800 sarcomeres were added to the lateral pterygoid muscle in controls animals, 
whereas only 490 sarcomeres were added to the muscle in treated rats (Oudet and Petrovic, 1981). In spite of the lower increase in sarcomere number, sarcomere length was still shorter in treated than in control rats, reaching only $2.25 \mu \mathrm{m}$ (fig. 1).

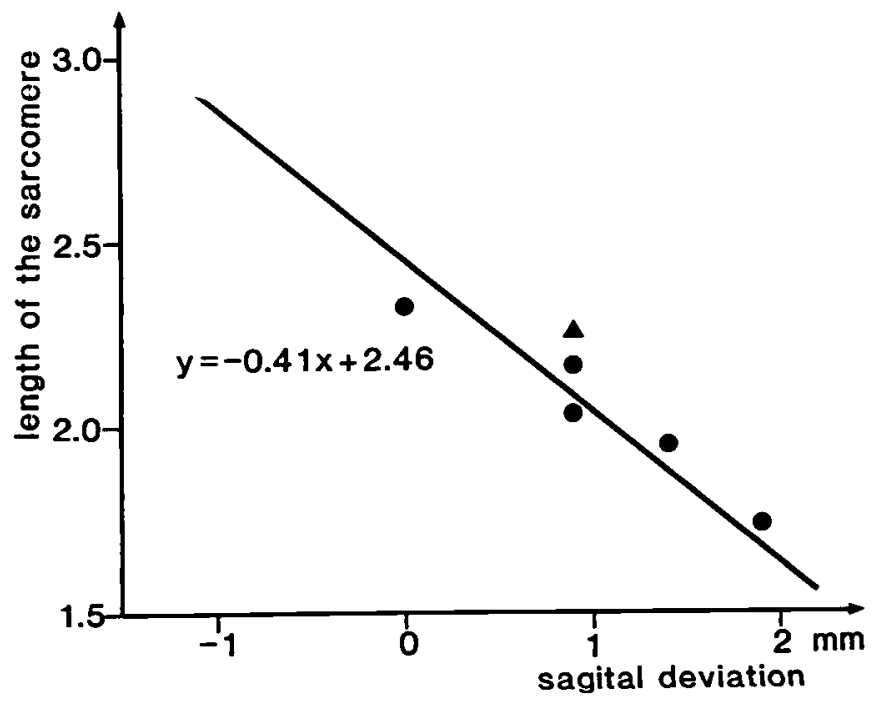

FIG. 1. - Length of the individual sarcomere as a function of the sagittal deviation of the occlusal adjustment : during fixation; $\boldsymbol{\Delta}$ after a 4 week treatment with a « postural hyperporpulsor " of the mandible (sagittal deviation, $1 \mathrm{~mm}$; mean value for 6 rats). Variations in the number of additional sarcomeres tend, with time, to restore the usual length of the sarcomere.

ATPase activity of lateral pterygoid muscle myosin in orthopedically-treated and non-treated rats.

In both controls and treated rats, ATPase activity enabled us to detect distinct types of fibres. So, after acid preincubation at $\mathrm{pH} 4.4$ ATPase activity revealed two different portions in the lateral pterygoid muscle:

- the superior part attached on the meniscus and including both type $I$ and type II fibres; type II was subdivided into type IIB, incidentally type IIA and type IIC (fig. 2),

- the inferior part attached on the condyle ; only fibres II were identified (fig. 3). Preincubation at $\mathrm{pH} 4.5$ however enabled us to distinguish between fibres IIB (fast-twitch and fatigable) and IIA (fast-twitch and non-fatigable).

In rats treated for 4 weeks with the postural hyperpropulsor of the mandible, the proportion of type IIA fibres was significantly increased (table 1). So, in the inferior part of the lateral pterygoid muscle, the proportion of non-fatigable fibre type was increased. 


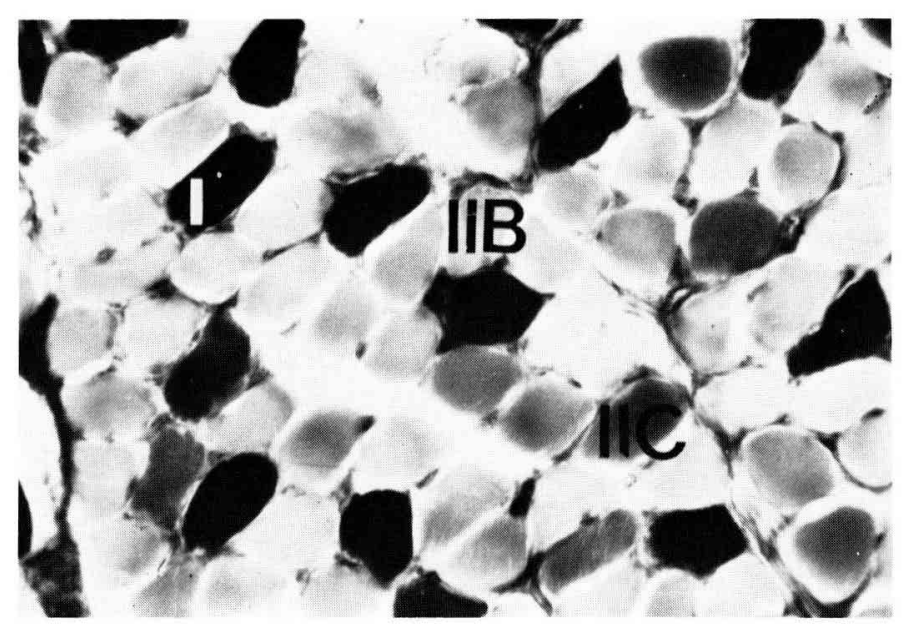

FIG. 2. - ATPase-activity of the superior portion of the lateral pterygoid muscle after acid (pH 4.4) preincubation. Type I fibres are black, type IIB are light grey and type IIC are dark-grey.
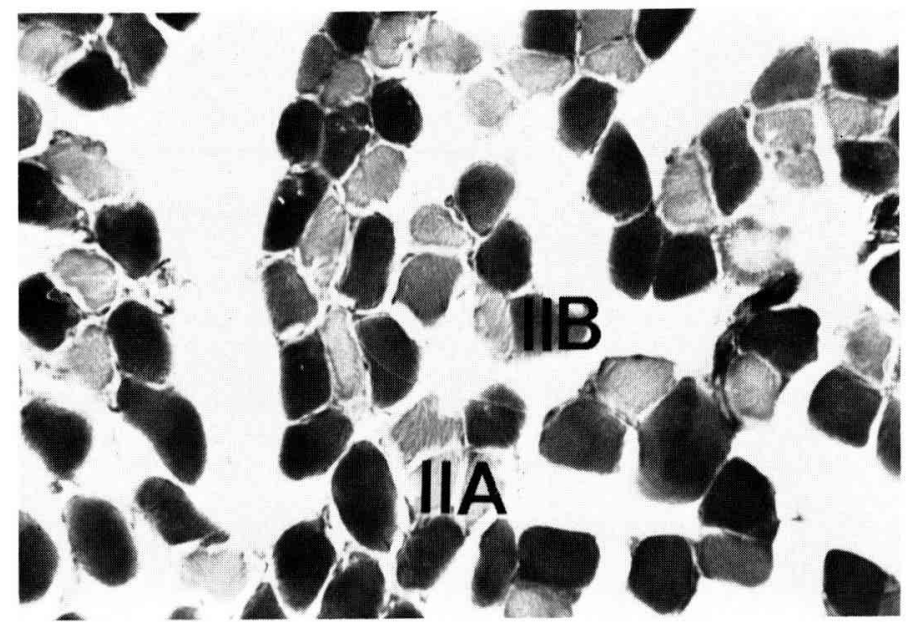

FIG. 3. - ATPase activity of the inferior portion of the lateral pterygoid muscle after acid (pH 4.5) preincubation. Type IIA fibres are light grey and type IIB fibres are dark-grey.

Polyacrylamide gel electrophoresis of myosin light chains in orthopedically-treated and non-treated rats.

Frozen sections of lateral pterygoid muscle were dissected to separate the upper part from the lower part. Fibre extracts from the lower portion of control rats displayed three light chains of myosin characteristic of fast-twitch muscle such as the tibialis (fig. 4). Fibre extracts from the lower portion of treated rats showed both the three light chains of fast myosin plus the two light chains characteristics of slow-twitch muscle such as the soleus (fig. 4). These slow light chains originated in the IIA fibres (Gauthier and Lowsey, 1979). 
TABLE 1

Effect of an orthopedic treatment of the mandible on the fibre type differentiation in the lateral pterygoid muscle. Percentages of IIA fibres.

\begin{tabular}{lcccc}
\hline & Number & Mean & Standard-error & t-test \\
\hline Controls & 10 & 30.31 & 1.658 & \\
\hline $\begin{array}{l}\text { Orthopedically } \\
\text { treated }\end{array}$ & 15 & 38.17 & 1.253 & $\mathrm{P}<0.84$ \\
\hline
\end{tabular}

\section{Discussion and concluding remarks.}

Therapeutically-induced forward positioning of the mandible brought the condyle nearer to the pterygoid process of the sphenoid (fig. 5) every time the mouth of the rat tended to close. The resulting reiterated physiological shortening of the lateral pterygoid muscle produced a repeated shortening of the individual sarcomeres, i.e. a greater overlapping of myosin and actin molecules and, as a consequence, the decrease of contractile force. In these circumstances, the reduced addition of newly-formed sarcomeres appeared to be a regulatory mechanism, i.e., the decreased length imposed therapeutically on the individual sarcomere produced a "deviation signal » (of unknown nature) that induced a further decrease in the addition of new sarcomeres. Thus, the individual sarcomere progressively recovered its initial length and its usual contractile force (fig. 6).

Anatomically, the rat lateral pterygoid muscle is an entity. However, in rats as in other mammals, its parts have a dual function (Christensen, 1969; Grant, 1973; McNamara, 1973) : the upper portion includes both slow and fast-fibre types. The lower part shows only fast-twitch fibres. IIM fibres, typical of muscles originating in the first branchial arch and containing super-fast myosin, have not been found in rat masticatory muscles (Rowlerson et al., 1983). In this respect, rats differ from humans less than monkeys or dogs.

Four weeks after the onset of orthopedic treatment using the postural hyperpropulsor of the mandible, the proportion of fast non-fatigable fibre types in lateral pterygoid muscle was increased significantly. The clinical advantage is that such variation in lateral pterygoid muscle facilitates the repeated forward movement of the mandible as well as its forward positioning during the time the appliance is not worn.

Through the increase of lateral pterygoid muscle activity, treatment using the postural hyperpropulsor increases the growth rate of the condylar cartilage and lengthens the mandible still more (Petrovic, Stutzmann and Oudet, 1975). The reported findings show that postural hyperpropulsion of the mandible also caused an increase in the number of fast-twitch non-fatigable fibres accompanied by an increase of slow-myosin light chains. These changes are similar to those occurring during muscle training (see Salmons and Henriksson, 1981). 

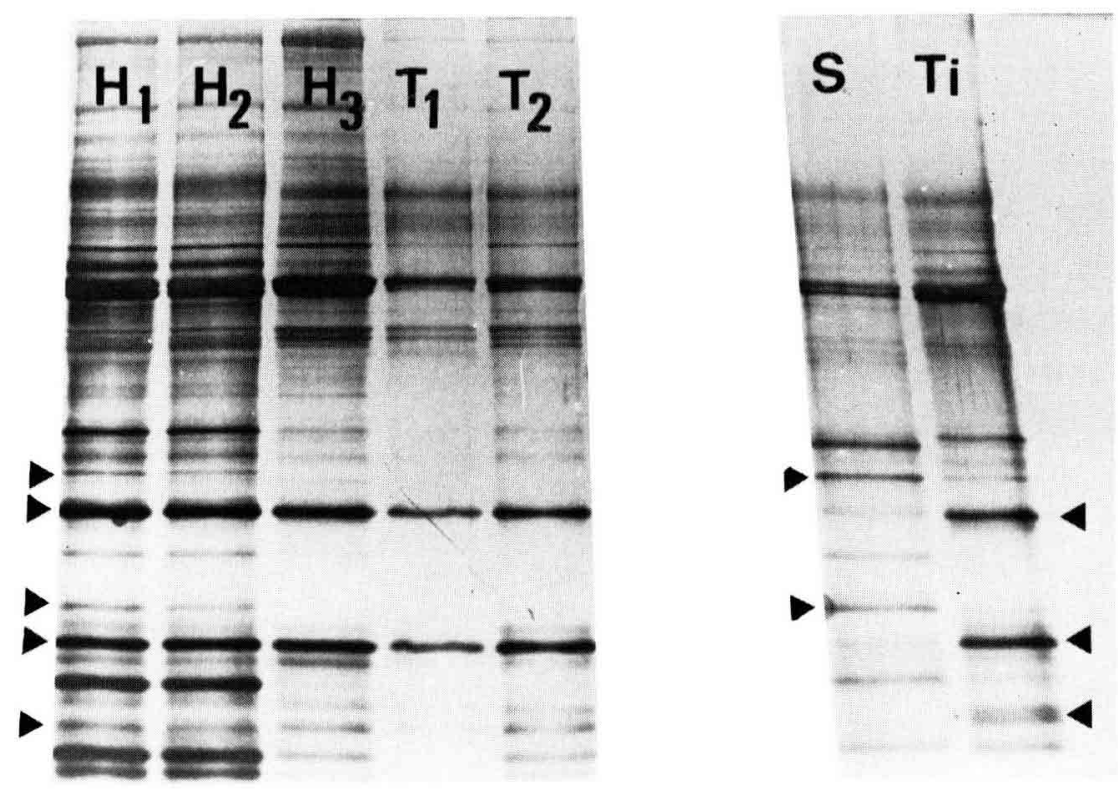

FIG. 4a. - Silver stained $15 \%$ polyacrylamide ge/ after SDS-electrophoresis: $\mathrm{H} 1, \mathrm{H} 2, \mathrm{H} 3$ : bands of fibre proteins from the lateral pterygoid muscle of rats treated during four weeks with the "postural hyperpropulsor" of the mandible; T1, T2: bands of fibre proteins from the lateral pterygoid muscle of control rats ; $\mathrm{S}$ : bands of the fibre proteins from the soleus; $\mathrm{Ti}$ : bands of the fibre proteins from the tibialis.

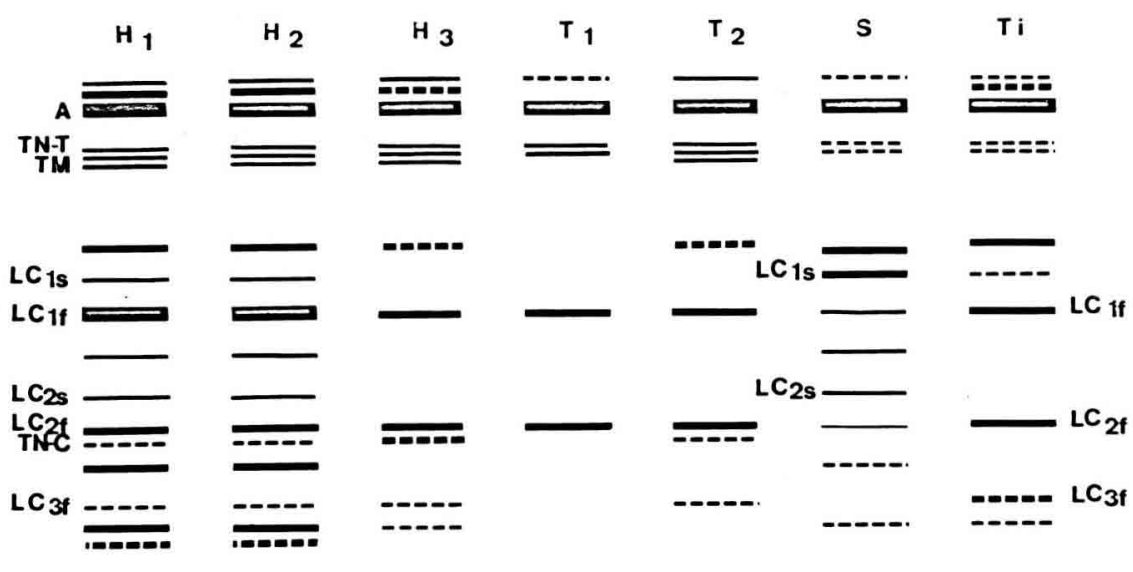

FIG. 4b. - Schematic representation of the ge/ and its interpretation: LC1 $f$, LC2f, LC3f, fast myosin light chains ; LC1s, LC2s, slow myosin light chains. 


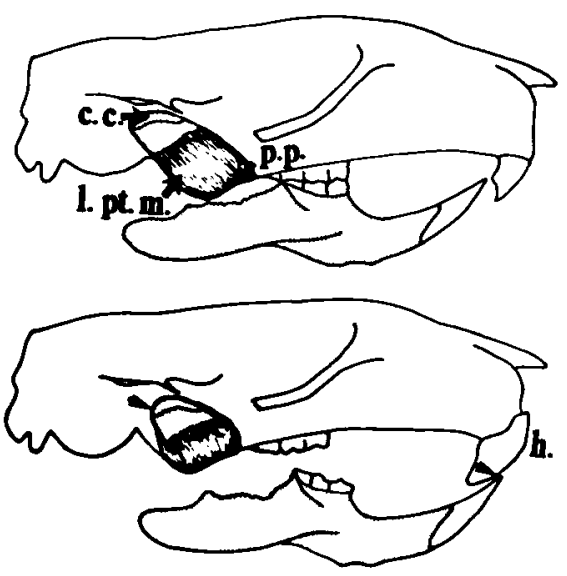

FIG. 5. - The fitting of the "postural hyperpropulsor" of the mandib/e, brings nearer the two attachments of the lateral pterygoid muscle: c.c., condylar cartilage of the mandible; p.p., pterygoid process of the sphenoid; I.pt.m., lateral pterygoid muscle; h, hyperpropulsor.

REGULATION OF THE NUMBER OF SERIAL SARCOMERES IN THE LATERAL

PTERYGOID MUSCLE DURING HYPERPROPULSION OF THE MANDIBLE

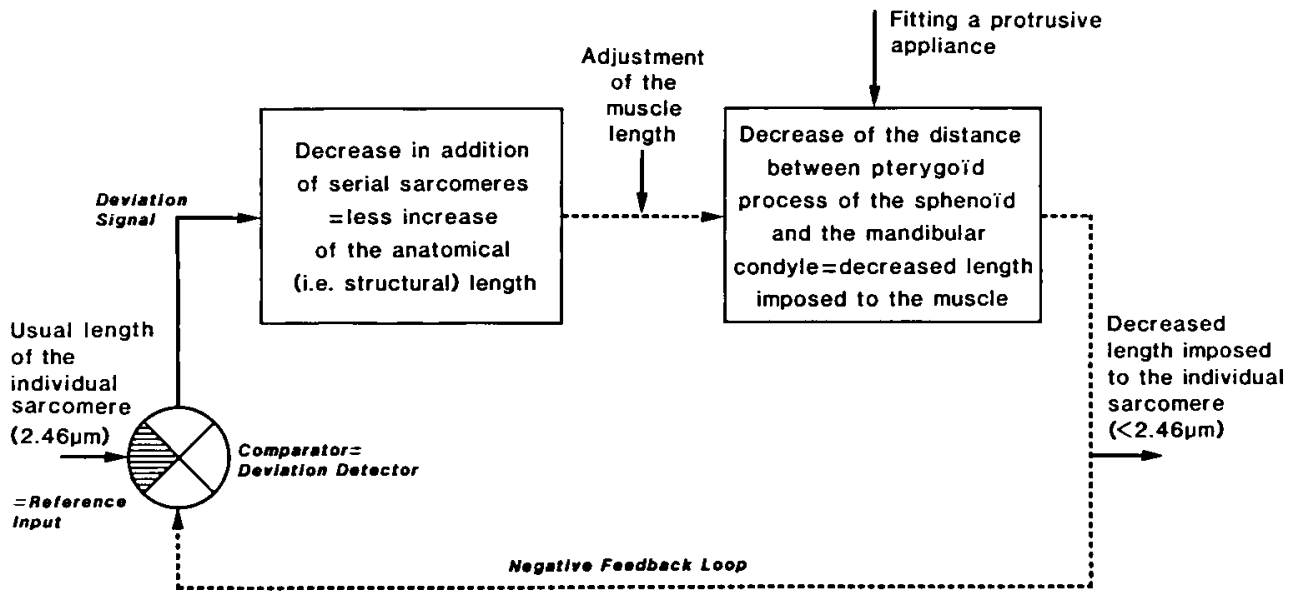

The Devistion signat is proportional to the difference between the usual length and the imposed length of the individual sarcomere

FIG. 6. - Functional diagram for the regulation of the number of sarcomeres in the lateral pterygoid muscle during hyperpropulsion of the mandible. 
Kantomaa and Rönning (1982) obtained an increase of condylar cartilage growth rate and of mandible lengthening by electrical stimulation of the lateral pterygoid muscle. It is known that continuous electrical stimulation causes a change in muscular features at the molecular level, i.e. fast-myosin is transformed into slow-myosin and, concomitantly, type II fibres into type I fibres (Salmons and Sreter, 1976).

Thus, electrical stimulation of lateral pterygoid muscle cannot be considered as an experimental model for the study of physiological changes occurring during orthopedic treatment.

$13^{e}$ Réunion du groupe Développement I.N.R.A. Cap d'Agde, 25-27 mai 1987.

Acknowledgements. - This work has been done with the technical assistance of Mrs Martine Morales.

Résumé. Nature des fibres et de la myosine du muscle ptérygoidien latéral après un traitement orthopédique de la mandibule chez le rat.

1. La mise en place d'un hyperpropulseur postural de la mandibule entraîne, chez le jeune rat, un positionnement antérieur de la mandibule lors de la fermeture de la bouche. La propulsion de la mandibule provoque un raccourcissement de la distance entre les deux insertions du muscle ptérygoïdien latéral. Par conséquent, la longueur du sarcomère individuel est périodiquement raccourcie. Après quatre semaines de traitement, le sarcomère individuel a une longueur de $2,2 \mu$ à $2,5 \mu$.

2. La portion méniscale du muscle ptérygoïdien latéral contient, à la fois des fibres à contraction lente (type I) et des fibres à contraction rapide (type $\| \mathrm{A}$, IIB et IIC). La portion condylienne du muscle ptérygoïdien latéral ne contient que des fibres rapides (type IIA et IIB). Pendant le traitement orthopédique par l'hyperpropulseur postural, la proportion de fibres IIA (à contraction rapide et peu fatigables) augmente par rapport à celle de fibres IIB (à contraction rapide et fatigables). Le muscle devenu moins fatigable, assure mieux le maintien de la mandibule en position avancée, même pendant les heures où le dispositif n'est pas porté. Après le traitement orthopédique par l'hyperpropulseur postural, on observe dans la portion condylienne du muscle ptérygoïdien latéral, une augmentation des chaînes lentes de la myosine qui trouve son origine dans l'augmentation du nombre des fibres IIA. Les changements sont analogues à ceux observés dans un muscle après l'entraînement physique (et diffèrent des modifications observées après la stimulation électrique continue).

\section{References}

ANSORGE W., 1983. Fast visualization of protein bands by impregnation in potassium permanganate and silver nitrate, 235-245. In STATHAKOS D. Proceedings of electrophoresis. De Gruyter, Berlin.

BROOKE H. M., KAISER K. K., 1970. - Muscle fibre types : how many and what kind? Arch. Neurol., 23. 369-379.

CHARLIER J. P., PETROVIC A., HERRMANN-STUTZMANN J., 1969. Effects of mandibular hyperpropulsion on the prechondroblastic zone of young rat condyle. Am. J. Orthodontics, $55,71-74$ 
CHRISTENSEN F. G., 1969. Some anatomical concepts associated with the temporomandibular joint. Ann. Aust. Coll. Dent. Surg., 2, 39-60.

GAUTHIER F. G., LOWSEY S., 1979. Distribution of myosin isoenzymes among skeletal muscle fiber types. J. Cell Biol., 81, 10-25.

GRANT P. G., 1973. Lateral pterygoid: two muscles? Am. J. Anat, 138, 1-10.

KANTOMAA A., RÖNNING O., 1982. The effect of electrical stimulation of the lateral pterygoid muscle on the growth of the mandible in the rat. Proc. Finn. Dent. Soc., 78, 215-219.

LAEMMLI U., 1970. Cleavage of structural proteins during the assembly of the head of bacteriophage T4. Nature, 227, 680-685.

MABUCHI K., PINTER K., ALLEN P., GERGELY J., SRETER F., 1981. Characteristics of rabbit and human single fibres. Adv. physiol. Sci., 24, 69-77. In GUBA F., MARECHAL G., TAKACS O., Mechanisms of muscle adaptation to functional requirements, Pergamon Press.

MCNAMARA J., 1973. The independent functions of the two heads of the lateral pterygoid muscle. Am. J. Anat., 138, 197-206

OUDET C., PETROVIC A., 1981. Regulation of the anatomical length of the lateral pterygoid muscle in the growing rat, Adv. Physiol. Sci., 24, 115-121. In GUBA F., MARECHAL G., TAKAC$\mathrm{S} \mathrm{O}$. ., Mechanisms of muscle adaptation to functional requirements, Pergamon Press.

PETROVIC A., 1975. Control of postnatal growth of secondary cartilages of the mandible by mechanisms regulating occlusion. Cybernetic model. Trans. Europ. Orthodont. Soc., 50, $65-75$.

PETROVIC A., STUTZMANN J., OUDET C., 1975. Control processes in postnatal growth of condylar cartilage of the mandible, 14-57. In McNAMARA J.A., Jr., Determinants of mandibular form and growth, Monograph 4, Cranio-facial Growth Series, Center for Human Growth and Development, Univ. Michigan, Ann Arbor, Michigan, USA.

PETROVIC A., 1984. An experimental and cybernetic approach to the mechanism of action of functional appliances on the mandibular growth, 213-268. In MCNAMARA J., RIBBENS K., Malocclusion and the periodontium. Cranio-facial Growth Series, Center for Human Growth and Development, Univ. Michigan, Ann Arbor, Michigan, USA.

PETROVIC A., LAVERGNE J., STUTZMANN J., 1986. Tissue-level growth and responsiveness potential, growth rotation, and treatment decision (pp. 181-223). In VIG P. S., RIBBENS K. S., Science and clinical judgment in orthodontics, Monograph 19, Cranio-facial Growth Series, Center of Human Growth and Development, Univ. Michigan, Ann Arbor, Michigan, USA.

RAYNE J., CRAWFORD G., 1972. The relationship between fibre length, muscle excursion and jaw movements in the rat. Arch. Oral Biol., 17, 859-872.

ROWLERSON A., MASCARELLO F., VEGETTI A., CARPENE E., 1973. The fibre-type composition of the first branchial arch muscles in Carnivora and Primates. J. Muscle Res. Cell Motility. 4. 443-472.

SALMONS S., HENRIKSSON J., 1981. The adaptive response of skeletal muscle to increased use. Muscle Nerve, 4, 94-105.

SALMONS S., SRETER F., 1976. Significance of impulse activity in the transformation of skeletal muscle type. Nature, 263, 30-34. 